\title{
Konstruksi Hukum Pembiayaan Al Qardh Al Hasan Pada Bank Syariah (Studi Kasus Pada Bank": Syariah Mandiri Cabang Yogyakarta)
}

\author{
Bagya Agung Prabowo
}

\begin{abstract}
Abstrak
The legally binding of a collateral contract on the Al Qardh Al Hasan on The Mandiri Syariah Bank in Yogyakarta indicates that the rules of Syariah does not regulate what kinds of collateral contracts. The procedure of collateral contract must be based on the rules of conventional law applied as a public regulation which legally binding to all Syariah Bank in Indonesia.
\end{abstract}

\section{Pendahuluan}

Pertumbuhan perbankan syariah tampaknya mengalami akselerasi sangat berarti dalam beberapa tahun terakhir ini. Harus diakui terbitnya Undang-Undang Nomor 10 Tahun 1998 tentang Perbankan, yang merupakan penyempurnaan dari UndangUndang Nomor 7 Tahun 1992,' telah memicu perkembangan perbankan syariah. Ketentuan UU No. 10 Tahun 1998 memungkinkan bank konvensional mengkonversi menjadi bank syariah berdasarkan dual banking system. ${ }^{2}$ Konversi sistem operasi perbankan dari konvensional ke sistem syariah pertama kali dimanfaatkan oleh Bank Susila Bhakti (BSB). Bank yang mayoritas sahamnya dimiliki Bank Dagang Negara (BDN), sebelum dimerger ke dalam Bank Mandiri per 1 November 1999, resmi menerapkan sistem syariah dan mengubah namanya menjadi Bank Syariah Mandiri (BSM). ${ }^{3}$

'Selanjutnya disebut UU No. 10 Tahun 1998.

${ }^{2}$ Dengan adanya UU No. 10 Tahun 1998 maka berlaku dual banking system pengelolaan bank, yaitu secara konversional dengan menggunakan bunga (interrest) untuk setiap peminjaman atau penyimpangan dana, serta menggunakan sistem bagi hasil yang merupakan dasar perbankan syariah.

${ }^{3}$ Bank Syariah Mandiri berdiri berdasarkan SK Gubemur Bank Indonesia No. 1/24/KEP.GBI/1999 tentang Perubahan Kegiatan Usaha Menjadi Berdasarkan Syariah dan SK Deputi Gubemur Senior Bank Indonesia No. 1/1/KEP.DGS/1999 mengubah nama menjadi PTBank Syariah Mandiri (BSM). Visi BSM adalah menjadi bank syariah terpercaya pilihan mitra usaha. Lihat $h$ ttp $/ /$ www.pikiran-rakyat.com/cetak/0303/03/0807.htm, diakses 15 September 2004. 
Sebagai lembaga berlandaskan syariah, BSM memiliki tanggung jawab sosial yang diimplementasikan dalam bentuk pengelolaan dan pembiayaan Al Qardh Al-Hasan bagi kaum dhuafa, para pengusaha kecil dan mikro di daerah-daerah, yaitu pemberian pinjaman bank kepada pihak kedua untuk kebutuhan mendesak atau sebagai dana talangan (over draft) dengan kriteria tertentu dan bukan untuk pinjaman yang bersifat konsumtif. Dana talangan tersebut dikembalikan sesuai dengan jumlah yang diterima dan pembayarannya dapat dilakukan secara angsuran atau sekaligus. Sumber dana Qardh diperoleh dari dana pihak III, modal, dan dana khsusus yang disediakan bank. Sedangkan dana yang diperoleh dari Muzakki atau kaum dermawan berbentuk zakat, infaq, sedekah, hibah, dan wakaf digunakan untuk bantuan yang bersifat sosial, seperti mendapat musibah. ${ }^{4}$

Idealitanya, pembiayaan Al Qardh Al Hasan ini hanya diperuntukkan bagi kaum dhuafa, para pengusaha kecil dan mikro di daerah-daerah yang membutuhkan dana pinjaman segera untuk masa yang relatif pelluek deriyan jaminan produksi usahanya. Pinjaman diberikan dengan dasar atau prinsip pinjam meminjam, di mana bank syariah tidak diperkenankan mengambil keuntungan dari dana yang dipinjamkan kecuali biaya administrasi dan nasabah wajib mengembalikan secepatnya uang yang dipinjamnya tersebut dengan memenuhi persyaratan. ${ }^{5}$

Realitanya tidaklah demikian, pihak Muqtaridh (peminjam) tidak selalu disyaratkan oleh pihak Muqridh (pemberi pinjaman) sebagaimana ketentuan dalam pembiayaan $A I$
Qardh Al Hasan- untuk memberikan jaminan. Jika melihat konstruksi hukumnya Qardh (pinjammeminjam) semestinya ada jaminannya, berbeda dengan Syirkah (persekutuan atau kerjasama) yang tidak perlu adanya jaminan. Jaminan pembiayaan Al Qardh Al Hasan bersifat antisipatif terhadap upaya penyalahgunaan keadaan, karena pihak Muqianidh tidak diharuskan mengembalikan pinjamannya jika usahanya tidak berhasil. Dengan demikian, institusi perbankan syariah mesti dikelola secara hati-hati (prudent) sesuai dengan ketentuan undang-undang dan prinsip syariah (Fatwa Dewan Syariah Nasional).

Berpijak dari uraian tersebut dalam tulisan ini akan dibahas beberapa permasalahan yaitu bagaimana konstruksi hukum pembiayaan $\mathrm{Al}$ Qardh Al Hasan pada Bank Syariah Mandiri Cabang Yogyakarta? Bagaimana kekuatan mengikat akad jaminan pembiayaan Al Qardh Al Hasan pada Bank Syariah Mandiri Cabang Yogyakarta?

\section{Sekilas Pengertian Bank Syariah dan Kegiatan Usahanya}

Daląm literatur perbankan Islam di Indonesia, istilah lain yang diperlukan untuk sebutan Bank Islam adalah Bank Syariah. Secara akademis, istilah Islam dengan syariah memang mempunyai pengertian lain. Namun secara teknis di Indonesia menyebutkan Bank Islam dan Bank Syariah mempunyai pengertian yang sama.

Munculnya Bank dengan prinsip syariah sebagai altematif sistem perbankan di Indonesia, dapat menjangkau lapisan masyarakat luas yang selama ini tidak dapat menerima pranata bunga.

\footnotetext{
${ }^{4} \mathrm{http}: /$ www.bmtlink.web.id/kamusbmt.htm, diakses 15 September 2004.

${ }^{5} \mathrm{http}: / /$ www.bprsyariah.com/subbiaya.php, diakses 15 September 2004.
} 
Fenomena ini sebagai salah satu sistem perbankan alternatif, telah berlaku secara internasional, baik dalam negara yang menggunakan konstitusi syariah Islam maupun di negara-negara yang berpemerintahan non Islam. ${ }^{6}$ Oleh karenanya keberadaan bank dengan prinsip syariah ini tidak tepat kalau dikatakan sebagai issue agama, melainkan issue sistem. ${ }^{7}$ Pada perkembangan berikutnya, lembaga perbankan Islam ini merambah keseluruh penjuru dunia. Dengan demikian, perbankan Islam yang menerapkan prinsip syariah ini dapat dikatakan telah diakui sebagai salah satu sistem perbankan dunia. ${ }^{8}$

Menurut Ensiklopedia Islam, Bank Islam ialah lembaga keuangan yang usaha pokoknya memberikan kredit dan jasa-jasa dalam lalu lintas pembayaran serta peredaran uang yang pengoperasiannya disesuaikan dengan prinsipprinsip syariah Islam. ${ }^{9}$ Berdasarkan rumusan tersebut, Bank Islam berarti bank yang tata cara beroperasinya didasarkan pada tata cara bermuamalah ${ }^{10}$ secara Islam, yakni mengacu pada ketentuan-ketentuan AI Quran dan Al Hadis.

Dalam kegiatannya, bank Islam harus mengikuti atau berpedoman pada praktikpraktik usaha yang dilakukan di jaman Rasulullah s.a.w, bentuk-bentuk usaha yang telah ada sebelumnya tetapi tidak dilarang oleh Rasulullah," atau bentuk usaha baru sebagai hasil ijtihad para ulama atau cendekiawan muslim yang tidak menyimpang dari ketentuan Al Qur'an dan Al Hadis. ${ }^{12}$

Dalam menjalankan aktivitas penyaluran dana kepada masyarakat sesuai dengan prinsip utama yang diterapkan, bank syariah secara garis besar dapat dibedakan menjadi tiga macam. ${ }^{13}$ Pertama, pembiayaan berdasarkan prisip bagi hasil; kedua, berdasarkan model jual beli dengan pengambilan keuntungan; ketiga, berdasarkan prinsip sewa. Masingmasing prinsip tersebut masih dijabarkan ke dalam beberapa jenis usaha yang sesuai dengan Hukum Islam, dalam hal ini Hukum Muamalah.

${ }^{6}$ Zainulbahar Noor, Membangun Citra Lewat Pengamalan Syariah, (Jakarta, Grasindo, 1993), hlm. 47

${ }^{7}$ Muhammad Said Hisyam, "Pemanfaatan Produk Bank Islam/Kredit Untuk Mendukung Lingkaran Bisnis Amanah", Makalah Seminar Nasional Bank Umum Tanpa Bunga, (Bandung, FE UNPAD, 1991), hlm. 35

${ }^{8}$ Muhammad Syafi'i Antonio, "Perkembangan Lembaga Keuangan Islam", dalam buku Arbitrase Islam di Indonesia, BMI-BAMUI, 1994, hlm. 29

${ }^{9}$ Abdul Azis Dahlan, Ensiklopedia Islam, Ichtiar Baru Van Hoeve, Jakarta, 1994, hlm. 28

${ }^{10}$ Muamalah ialah ketentuan-ketentuan yang mengatur hubungan manusia dengan manusia, baik hubungan pribadi maupun antara perorangan dengan masyarakat. Muamalah ini meliputi bidang kegiatan jual-beli (bai), bunga (riba), piutang (qard), gadai (rahan), memindahkan utang (hawalah), bagi untung dalam perdagangan (qirad), jaminan (dhamanah), persekutuan (syirkah), persewaan dan perburuhan (ijarah).

"Bentuk-bentuk perdagangan sejak pra Islam yang sampai sekarang dikembangkan dalam dunia bisnis modern antara lain al musyarakah (joint venture), al Bai'at-Takjiri (venture capita), al ljarah (leasing), at lakaful (insurance), al Bil'u Bithaman Ajll (instalment-sale), al Murabahah (kredit pemilikan barang), riba (pinjaman dengan tambahan bunga).

${ }^{12}$ Warkum Sumitro, Asas-asas Perbankan Islam Dan Lembaga-lembaga Terkait Di Indonesia, (Jakarta, Raja Grafindo Persada, 1992), him. 41

${ }^{13}$ Faisal Afif et-al, Strategi dan Operasional Bank, (Bandung, Eresco, 1996), hlm. 24 
Hubungan pinjam-meminjam dalam Islam tidak dilarang, bahkan dianjurkan agar terjadi hubungan saling menguntungkan, yang pada gilirannya berakibat pada hubungan persaudaraan. Namun Perbankan Syariah, penggunaan kata "pinjam-meminjam" kurang tepat digunakan, hal ini disebabkan oleh, Pertama; pinjaman merupakan salah satu metode hubungan finansial, dalam Islam masih banyak metode yang diajarkan oleh syariah selain pinjaman, seperti jual beli, bagi hasil, sewa, dan sebagainya. Kedua, dalam Islam, pinjammeminjam adalah akad sosial, bukan akad komersial. Artinya, bila seseorang meminjam sesuatu, ia tidak boleh disyaratkan untuk memberikan tambahan atas pokok pinjamannya. Hal ini didasarkan pada hadis Nabi saw yang mengatakan bahwa setiap pinjaman yang menghasilkan manfaat adalah riba, sedangkan para ulama sepakat bahwa riba itu haram. Karena itu, dalam perbankan syariah, "pinjaman" tidak disebut "kredit", tapi "pembiayaan" (financing).

Jika seseorang datang ke bank syariah dan ingin meminjam dana untuk membeli barang tertentu, misalnya mobil atau rumah, suka atau tidak ia harus melakukan jual beli dengan bank syariah. Di sini, bank syariah bertindak selaku penjual dan nasabah bertindak selaku pembeli. Jika bank memberikan pinjaman (dalam pengertian konvensional) kepada nasabah untuk membeli barang-barang itu, bank tidak boleh mengambil keuntungan dari pinjaman itu. Sebagai lembaga komersial yang mengharapkan keuntungan, bank syariah tentu tidak mungkin melakukannya. Karena itu, harus dilakukan jual beli di mana bank syariah dapat mengambil keuntungan dari harga barang yang dijual dan keuntungan dari jual beli dibolehkan dalam Islam. ${ }^{14}$

\section{Pengertian dan Arti Penting Pembiayaan Al Qardh Al Hasan}

Dalam Kamus Istilah BMT, kata "AI Qardh" berarti akad pemberian pinjaman bank kepada pihak kedua untuk kebutuhan mendesak atau sebagai dana talangan (over draft) dengan kriteria tertentu dan bukan untuk pinjaman yang bersifat konsumtif. Dana talangan tersebut dikembalikan sesuai dengan jumlah yang diterima dan dan pembayarannya dapat dilakukan secara angsuran atau sekaligus. Sumber dana Al Qardh diperoleh dari dana pihak III, modal, dan dana khusus yang disediakan bank. Sedangkan dana yang diperoleh dari Muzakki atau kaum Dermawan berbentuk Zakat, Infaq, Sedekah, Hibah, Wakaf dan sebagainya digunakan untuk bantuan yang bersifat sosial (seperti mendapat musibah). Dana tersebut disalurkan dalam bentuk Al Qardh Al Hasan. Sedangkan kata "Al Hasan" sering diartikan dengan "kebaikan", di mana dalam setiap kebaikan itu senantiasa - mengandung manfaat. Dengan demikian, dalam bidang pembiayaan istilah $A /$ Qardh $A l$ Hasan bermakna pinjaman kebaikan. ${ }^{15}$

Dari definisi-definisi Al Qardh Al Hasan secara umum di atas apabila diterapkan dalam dunia perbankan bisa diberi batasan pengertian, yaitu sebagai salah satu bentuk usaha atau kegiatan pemberian pinjaman bank sebagai pihak Muqridh kepada pihak

\footnotetext{
${ }^{14} \mathrm{http}: / /$ ww.pikiran-rakyat.com/cetak/1003/01/0105.htm, diakses 15 September 2004

${ }^{15} \mathrm{http}: / /$ www.bmtlink.web.id/kamusbmt.htm, diakses 14 Oktober 2004
} 
kedua sebagai pihak Muqtaridh untuk kebutuhan mendesak atau sebagai dana talangan (over draft) dengan kriteria tertentu dan bukan untuk pinjaman yang bersifat konsumtif. Dana talangan tersebut dikembalikan sesuai dengan jumlah yang diterima dan pembayarannya bisa dilakukan secara angsuran atau sekaligus.

Ada beberapa alasan mengapa terhadap lembaga perbankan syariah perlu diterapkan Al Qardh Al Hasan secara khusus, tidak sebagaimana lembaga keuangan lain maupun badan-badan usaha lainnya.

1. Lembaga perbankan syariah mempunyai posisi yang sangat strategis dalam pembangunan nasional. Hal ini dapat dimengerti, karena perbankan syariah sebagai salah satu penggerak roda perekonomian dan pendukung utama pelaksanaan kebijaksanaan moneter yang efektif di Indonesia.

2. Dari pengertian bank sebagai lembaga, menurut Undang-undang No. 23 Tahun 1999 tentang Bank Indonesia adalah badan usaha yang menghimpun dana dari masyarakat dalam rangka meningkatkan taraf hidup rakyat banyak. Dari pengertian tersebut bisa dipahami bahwa bank syariah dalam operasionalisasi usahanya pada dasarnya memanfaatkan dana dari masyarakat penyimpan untuk masyarakat peminjam. ${ }^{16}$ Namun, tidak selalu masyarakat peminjam ini mampu mengembalikan pinjamannya. Dengan demikian, dalam pengoperasian suatu bank syariah bisa dikatakan pembiayaan Al Qardh Al Hasan ini sangat berarti guna membantu masyarakat peminjam yang tidak mampu mengembalikan pinjamannya, tetapi memiliki usaha produktif yang dapat dijadikan sebagai suatu jaminan.

3. Sumber dana Al Qardh Al Hasan di antaranya diperoleh dari dana pihak III, dari Muzakki atau kaum Dermawan berbentuk Zakat, Infaq, Sedekah, Hibah, Wakaf yang memang peruntukannya khusus untuk delapan asnaf (golongan). Di sinilah lembaga perbankan syariah berperan untuk membantu menyalurkan dana tersebut dalam upaya mendorong usaha-usaha produktif yang dikelola oleh masyarakat yang tidak mampu.

\section{Jaminan dalam Pembiayaan Al Qardh Al Hasan pada Bank Syariah}

Bank sebagai lembaga intermediary, salah satu fungsinya adalah memberikan pembiayaan. Kegiatan pembiayaan (financing) merupakan salah satu tugas pokok bank, yaitu pemberian fasilitas penyediaan dana untuk memenuhi kebutuhan pihak-pihak yang memerlukan deficit unit. Dalam kegiatan penyaluran dana, bank syariah melakukan investasi karena prinsip yang digunakan adalah penanaman dana atau penyertaan dan keuntungan yang akan diperoleh bergantung kepada kinerja usaha yang menjadi objek penyertaan tersebut sesuai nisbah bagi hasil yang telah diperjanjikan sebelumnya. Disebut pembiayaan, karena bank syariah menyediakan dana guna membiayai kebutuhan nasabah yang memerlukan dan layak memperolehnya. Dua jenis kegiatan tersebut sering dilistilahkan dengan penyebutan yang sama, yaitu "pembiayaan".

Dari pembiayaan yang diberikan tersebut, maka pendapatan bagi hasil atau keuntungan

${ }^{16}$ Surat Edaran Bank Indonesia No. 26/1/BPPP, 1993. 
jual-beli yang memerlukan instrumen pembiayaan perbankan syariah merupakan sumber pendapatan yang dominan. Pada saat pemberian pembiayaan, terkandung di dalamnya risiko bagi bank dan pengusaha. Dalam hal terjadi risiko atau musibah, maka kemungkinan kerugian akan timbul bagi keduanya.

Khusus kerugian yang dialami suatu bank, tidak saja merugikan bank itu sendiri tetapi juga berakibat kepada masyarakat penyimpan dan pengguna dana secara keseluruhan. Maka pihak bank dalam hal ini, sebagai upaya mengeliminasi kerugian yang terjadi, sejak dini harus menerapkan prinsip kehati-hatian dan asas pembiayaan yang sehat. Perbankan syariah sebagai sub-sistem dari perbankan nasional dalam menerapkan prinsip kehati-hatian dan asas pembiayaan yang sehat, diwujudkan antara lain dengan adanya jaminan atau agunan (collaterai) dari nasabah debitur. ${ }^{17}$

Jaminan atau agunan ini berfungsi untuk mendukung keyakinan bank atas kemampuan dan kesanggupan nasabah untuk melunasi pembiayaan yang diterimanya sebagaimana yang telah diperjanjikan. Jaminan tersebut sifatnya baik berupa materiil (kebendaan) maupun immaterial (perseorangan). ${ }^{18}$ Jaminan yang bersifat perorangan atau penanggungan dapat berbentuk jaminan pribadi (personal guarantee) maupun yang berbentuk jaminan perusahaan (company guarantee), sedangkan jaminan yang bersifat kebendaan termasuk mengenai pengikatan barang sebagai jaminan utang (agunan) antara lain diatur dalam ketentuan yang berlaku mengenai Hak Tanggungan, Hipotik, Jaminan Fiducia dan Gadai.

Dalam KUHPerdata Pasal 1820 dinyatakan bahwa penanggungan adalah suatu persetujuan dengan mana seorang pihak ketiga, guna kepentingan si berpiutang, mengikatkan diri untuk memenuhi perikatannya si berutang manakala orang ini sendiri tidak memenuhinya. Dalam Hukum Islam, istilah jaminan atau penanggungan sebagaimana dimaksud Pasal 1820 KUHPerdata di atas, biasa dikenal dengan istilah kafalah. Sedangkan objek atau barang yang dijaminkan dikenal dengan istilah rahn. Adapun bentuk pengikatan terhadap objek atau barang yang dijaminkan, tidak diatur dan dinyatakan secara rinci, tetapi merupakan formulasi dari prinsip-prinsip umum dalam muamalah sesuai dengan kebiasaan (urf) dalam masyarakat.

Kafalah secara bahasa (Arab) dapat diartikan; menggabungkan (al dhammu), menanggung (hamalah), dan menjamin (za'amah). Sedangkan menurut istilah, kafalah adalah mempersatukan tanggung jawab dengan tanggung jawab lainnya dalam hal funtutan secara mutlak, baik berkaitan dengan jiwa, utang, materi, maupun pekerjaan. Pengertian lain dari kafalah adalah jaminan yang

${ }^{17}$ Pasal 8 UU No. 10 Tahun 1998 jo No. 7 Tahun 1992 tentang Perbankan.

${ }^{18}$ Jaminan perorangan adalah suatu perjanjian antara seorang berpiutang (kreditor) dengan seorang ketiga yang menjamin dipenuhinya kewajiban-kewajiban si berutang (debitur). la bahkan dapat diadakan di luar (tanpa) sepengetahuan si berutang tersebut. Sedangkan jaminan kebendaan, dapat diadakan antara kreditor dengan debiturnya, tetapi juga dapat diadakan antara kreditor dengan seorang ketiga yang menjamin dipenuhinya kewajiban-kewajiban si berutang (debitur). Lihat; R. Subekti, Jaminan-jaminan untuk Pemberian Kredit menurut Hukum Indonesia, (Bandung, Citra Aditya Bakti, 1991), hlm. 15. 
diberikan oleh penanggung (kafii) kepada pihak ketiga untuk memenuhi kewajiban pihak kedua atau yang ditanggung (maktul'anhu, ashi). ${ }^{19}$

Sedangkan kata rahn, secara bahasa berarti tetap dan lestari serta penahanan (al hasabu), sebagaimana dikatakan ni'matun rahinah, yang artinya "karunia yang tetap dan lestari" dan sebagaimana pula dijelaskan Al Quran, "Tiap-tiap pribadi terikat atau tertahan (rahinah) atas apa yang telah diperbuat (QS. Al Mudatsir: 38).

Ulama Malikiyah mendefinisikan rahn sebagai "Harta yang dijadikan pemiliknya sebagai jaminan utang yang bersifat mengikat." Ulama Hanafiyah mendefinisikan terminologi rahn sebagai "Menjadikan sesuatu (barang) jaminan terhadap hak (piutang) yang mungkin sebagai pembayar hak (piutang) itu, baik seluruhnya maupun sebagian." Sedangkan Ulama Syafi'yah dan Hambaliyah mendefinisikan rahn sebagai "Menjadikan materi (barang) sebagai jaminan utang yang dapat dijadikan pembayar utang apabila orang yang berutang tidak dapat membayar utangnya itu".

Pengertian rahn menurut Sayyid Sabiq, adalah "Ja'lu 'Ainin Laha Qimatun Maliyah fi Nadzri al Syar'l Bihaitsu Yumkinu Akhdzu al Dain au Akhdzu Ba'dhuhu Mintilka al 'Ain'. ${ }^{20}$ Artinya, menjadikan barang yang mempunyai nilai harta menurut ajaran Islam sebagai jaminan utang, sehingga orang yang bersangkutan (kreditor) dapat mengambil piutang atau mengambil sebagian manfaat barang itu.
Adapun rukun kafalah sebagaimana yang disebutkan dalam beberapa literatur figh adalah:

1. Pihak penjamin atau penanggung (kafi) baligh (dewasa) dan berakal sehat serta berhak penuh melakukan tindakan hukum dalam urusan hartanya dan rela (ridha) dengan tanggungan kafalah tersebut.

2. Pihak yang berutang (makful'anhu/ashil) sanggup menyerahkan tanggungannya (piutang) kepada penjamin dan dikenal oleh penjamin.

3. Pihak yang berpiutang (makful lahu) Diketahui identitasnya, dapat hadir pada waktu akad atau memberikan kuasa dan berakal sehat.

4. Objek jaminan (makful bih).

a. Merupakan tanggungan pihak atau orang yang berutang (ashil), baik berupa uang, benda maupun pekerjaan.

b. Dapat dilaksanakan oleh penjamin.

c. Harus merupakan piutang mengikat (lazim) yang tidak mungkin hapus, kecuali setelah dibayar atau dibebaskan.

d. Harus jelas nilai, jumlah dan spesifikasinya.

e. Tidak bertentangan dengan syariah (tidak diharamkan). ${ }^{21}$

Para ulama figh menyatakan bahwa pada dasamya setiap orang dapat menerima jaminan atau tanggungan dari pihak lain, selama pihakpihak tersebut mau menanggungnya dari pihak

${ }_{19}$ Wahbah Azzhaily, Al Figh al Islam waAdillatuh, (Damaskus, Dar al Fikr, 1989, Jilid V), hlm. 132, lihat pula Sayyid Sabiq, Fiqh al Sunnah, (Beirut, Dar al Fikr, 1992, jilid III), hlm. 283.

${ }^{20} \mathrm{Ibid}$.

${ }^{21}$ Wahbah Azzuhaily, op. cit, him. 140 - 147. Lihat juga, Dewan Syariah Nasional, Himpunan Fatwa DSN - MUI, BI dan DSN, (Jakarta, 2001), him. 72-73 
yang ditanggungnya masih hidup. Sedangkan bagi orang yang sudah meninggal dan tidak meninggalkan harta warisan, para ulama berbeda pendapat. Menurut Imam Malik dan Syafi' boleh ditanggung. Alasannya, berdasarkan hadis di atas tentang ketidaksediaan $\mathrm{Nabi}$ Muhammad saw menshalatkan jenazah karena meninggalkan sejumlah utang. Sedangkan Imam Abu Hanifah menyatakan tidak boleh, dengan alasan bahwa tanggungan tersebut tidak berkaitan sama sekali dengan orang yang tidak ada. Di samping itu, para fuqaha' selain Imam Abu Hanifah, juga berpendapat mengenai bolehnya memberikan tanggungan kepada orang yang dipenjara atau orang yang sedang dalam keadaan bepergian (musafir).22

Menurut Ibnu Rusyd, para fuqaha' berpendapat bahwa masa tanggungan itu berlaku sejak tetapnya hak atas orang yang ditanggung, terutama tanggungan harta. Sedangkan tanggungan dengan badan, tetapnya hak setelah adanya konfirmasi dengan pihak penanggung dan menyatakan kebersediaannya menjadi penanggung. Dengan tetapnya hak tanggungan tersebut, orang yang menerima tanggungan berhak menuntut kepada penanggung untuk memerima haknya.

Para ulama berbeda pendapat mengenai kapan dan berapa lama efektifnya hak tersebut. Namun secara umum mereka sepakat bahwa efektifnya hak tersebut adalah ketika debitur dapat menyampaikan bukti-bukti yang kuat atau saksi. Sedangkan mengenai waktu pembuktian lama waktunya sangat relatif, ada yang mengatakan 5 hari dan ada yang mengatakan 3 hari. Munculnya perbedaan pendapat tersebut hanya ingin menandaskan bahwa penanggungan itu harus benar-benar terjadi agar hak dan kewajiban para pihak dapat dijalankan dengan sebaik-baiknya. ${ }^{23}$

Apabila ada orang yang ditanggung itu berpergian jauh atau "menghilang", maka mengenai tanggung jawab orang yang menanggung ada tiga pendapat, Pertama, Penanggung wajib mendatangkan orang yang ditanggung, atau mengganti kerugian. Pendapat ini dikemukakan oleh Imam Malik beserta pengikutnya dan fuqaha' Madinah. Kedua, Penanggung dipenjarakan, sampai si tertanggung datang sehingga orang yang ditanggung telah datang atau jika ia mati, telah diketahui kematiannya. Ini pandangan Imam Abu Hanifah dan fuqaha' Irak. Ketiga, Penanggung tidak terkena kewajiban apapun termasuk dipenjarakan, kecuali ia mendatang-kannya, jika ia mengetahui tempatnya. Ini pendapat Abu 'Ubaid al Qasim.

Pendapat Imam Malik yang mengatakan, bahwa penanggung harus menanggung kerugian atas yang ditanggung apabila ia pergi, didasarkan pada hadis ibnu 'Abbas r.a. sebagai berikut:

"Sesungguhnya seorang laki-laki meminta debiturnya agar memberikan hartanya kepadanya, atau ia memberikan penanggung kepadanya, tetapi ia tidak mampu, sehingga orang tersebut mengadukannya kepad Nabi Muhammad saw. Maka Nabi Muhammad saw pun menanggungnya, kemudian debitur memberikan harta kepadanya"

Hadis tersebut menunjukkan adanya

${ }^{22}$ Ibnu Rusyd, Bidayah al Mujtahid wa Nihayah wa al Mugtadhid, (Vol. 3, Dar al Fikr, Beirut, Libanon, tanpa th), hlm. 224.

${ }^{23} \mathrm{lbid}$, hlm. 223. 
penggantian kerugian secara mutlak. Berbeda dengan fuqaha' Irak yang berpandangan bahwa, penanggung hanya berkewajiban menghadirkan apa yang ditanggungnya, yakni orang (yang ditanggungnya). Karenanya, penanggungan tersebut tidak harus menyertakan harta, kecuali apabila penanggungan tersebut memang disyaratkan demikian atas dirinya.

Selanjutnya, Imam Malik berpendapat apabila seseorang mensyaratkan tanggungan (badan) tanpa harta, sedangkan iapun menjelaskan syarat tersebut, maka harta tersebut tidak wajib atasnya. Apabila harta tersebut menjadi beban kewajibannya, berarti ia melakukan perbuatan yang melawan apaapa yang disyaratkan itu.

Berbeda dengan tanggungan harta, fuqaha' telah sepakat, bahwa apabila orang yang ditanggung tersebut meninggal atau pergi, maka penanggung harus mengganti kerugian.

Pandangan yang membolehkan kreditur menuntut penanggung, baik yang ditanggung itu bepergian atau tidak, kaya atau miskin, hal . itu beralasan berkaitan dengan hadis Qubaishah bin al Makhariqi ra.: "Aku membawa tanggungan, maka aku mendatangi Nabi Muhammad saw., kemudian aku bertanya kepada beliau tentang tanggungan itu. Maka beliau bersabda: "Kami akan mengeluarkan tanggungan itu atas namamu dari onta sedekah. Ya Qubaishah! Sesungguhnya perkara ini tidak halal, kecuali pada tiga hal", kemudian beliau menyebutkan tentang seorang laki-laki yang membawa suatu tanggungan dari laki-laki lain, sehingga ia melunasinya". Hadist tersebut di atas memberikan petunjuk, bahwa Nabi Muhammad saw membolehkan penuntutan terhadap penanggung, tanpa mempertimbangkan kondisi orang yang ditanggung..$^{24}$ Objek tanggungan, menurut sebagian besar ulama figh adalah harta, hal ini didasarkan kepada hadis Nabi Muhammad saw: "Az za'imu gharimun" (Penanggung itu menanggung kerugian).

Sehubungan dengan kewajiban yang harus dipenuhi oleh penanggung berupa harta, maka hal ini dikategorikan menjadi tiga hal, yaitu:

1. Tanggungan dengan utang, yaitu kewajiban membayar utang yang menjadi tanggungan orang lain dan dalam masalah utang, disyaratkan hendaknya nilai barang tersebut tetap pada waktu terjadinya transaksi tanggungan atau jaminan, dan barangnya diketahui, karena apabila tidak diketahui, dikhawatirkan akan terjadi gharar.

2. Tanggungan dengan materi, yaitu kewajiban menyerahkan materi tertentu yang berada di tangan orang lain. Jika berbentuk bukan jaminan seperti 'ariyah (pinjaman) atau wadi'ah (titipan), maka kafalah tidak sah.

3. Tanggungan dengan harta, yaitu jaminan yang diberikan oleh seorang penjual kepada pembeli karena adanya risiko yang mungkin timbul dari barang yang dijual belikan. ${ }^{25}$

Wahbah Al Zuhaili dan Sayyid Sabiq memberikan penjelasan tentang pembagian kafalah sebagai berikut:26

1. Kafalah bil $\mathrm{Mal}$, adalah jaminan pembayaran barang atau perlunasan

\footnotetext{
${ }^{24} \mathrm{Ibid}, \mathrm{hlm} .222-223$.

${ }^{25}$ Sayyid Sabiq, op. cit. him. 286 - 287

${ }^{26}$ Ibnu Taimiyah, Majmu al Fatawa Shaikh al/slam, (Riyadh, MaktabialRiyadh, 1963, Vol. XXIX), hlm. 549
} 
utang. Bentuk kafalah ini merupakan sarana yang paling luas bagi bank untuk memberikan jaminan kepada para nasabahnya dengan imbalan fee tertentu.

2. Kafalah bin Nafs, adalah jaminan diri dari si penjamin. Dalam hal ini bank dapat bertindak sebagai judicial personality yang dapat memberikan jaminan untuk tujuan tertentu.

3. Kafalah bit Taslim, adalah jaminan yang diberikan untuk menjamin pengembalian barang sewaan pada saat masa sewa berakhir. Jenis pemberian jaminan ini dapat dilaksanakan oleh bank untuk keperluan nasabahnya dalam bentuk kerjasama dengan perusahaan, leasing company. Jaminan pembayaran bagi bank dapat berupa deposito/tabungan dan pihak bank diperbolehkan memungut fee kepada nasabah tersebut.

4. Kafalah al Munjazah, adalah jaminan yang tidak dibatasi oleh kurun waktu tertentu dan untuk tujuan/kepentingan tertentu. Dalam dunia perbankan, kafalah model ini dikenal dengan bentuk perfomance bond atau jaminan prestasi. Menurut Wahbah AI Zuhaili, kafalah ini pada dasarnya merupakan akad kebaikan (tabarru') dan saling tolong-menolong (ta'awun). Penjamin (kafii) berhak menerima kembali sejumlah jaminan yang diberikannya kepada orang yang dijamin (makful anhu) tanpa menerima tambahan (muqabi). Namun, apabila orang yang menjamin mau memberikan hadiah atau imbalan, maka boleh menerimanya sesuai dengan kebiasaan (urf). Adapun menunt Abdul Sa'i al Misri, seorang penanggung/ penjamin haruslah mendapatkan upah sesuai dengan pekerjaannya sebagai penjamin. Pendapat ini membuka peluang dimasukkannya pertimbangan besamya risiko yang dipikul oleh si penjamin dalam memperhitungkan upahnya. Akibat hukum kafalah adalah:

1. Penjamin (kafii) wajib menjamin sepenuhnya apabila orang yang ditanggung tidak ada (pergi atau menghilang) dan ia tidak dapat keluar dari kafalah, kecuali dengan jalan memenuhi hutang yang menjadi beban 'ashil (orang yang ditanggung).

2. Pemegang jaminan (makful lahu) berhak mengembalikan warkat penanggungan sehingga penanggungan dengan sendirinya menjadi batal (fasakh). ${ }^{27}$

Ketentuan-ketentuan berkaitan dengan Rahn dapat digambarkan sebagai berikut:

1. Rukun Rahn

Para ulama figh berbeda pendapat dalam menetapkan rukun rahn, namun bila digabungkan, menurut jumhur ulama rukun rahn ada lima, yaitu: Rahin (orang yang menggadaikan), Murtahin (orang yang menerima gadai), Marhun (obyekbarang gadai), Marhun Bih (hutang) dan Shigat (ijab-qabul).

2. Syarat-syarat Rahn

Para ulama fiqh mengemukakan syaratsyarat sesuai dengan rukun rahn itu sendiri, yaitu:

a. Para pihak dalam pembiayaan rahn (Rahin dan Murtahin). Para pihak yang melakukan akad rahn adalah cakap bertindak menurut hukum (ahliyyah).

b. Adanya kesepakatan Shigat (ijab-qabu).

c. Marhun Bih (hutang), wajib dibayar kembali oleh debitur (Rahin) kepada kreditur (Murtahin), utang boleh dilunasi dengan

${ }^{27}$ Sayyid Sabiq, op. cit., hlm. 287 
agunan dan hutang harus jelas dan tertentu (dapat dikuatifikasikan jumlahnya).

d. Marhun (barang):

1) Karakteristik Barang. Menurut ahli hukum Islam (fuqaha), karakteristik barang jaminan utang sebagai berikut:
a) Bernilai harta dan dapat diperjual belikan.
b) Jelas dan tertentu.
c) Milik sah orang yang berutang.
d) Tidak terkait dengan hak orang lain.
e) Merupakan harta yang utuh.
f) Boleh diserahkan baik materi maupun manfaatnya.
2) Jenis Barang.

a) Berdasarkan Ketentuan Syariah. Dengan melihat praktik Nabi Muhammad saw dan para sahabat, bahwa barang yang dapat dijadikan jaminan utang rahndapat berupa kebun, baju besi dan hewan ternak. Oleh karena itu para ulama berpendapat bahwa barang yang dapat dijadikan jaminan hutang (rahn) pada prinsipnya adalah barang yang bergerak dan tidak bergerak.

b) Penguasaan Barang yang digadaikan. Para ulama sepakat bahwa rahnitu dianggap sempurna apabila barang yang digunakan itu secara hukum sudah berada di tangan pemberi hutang dan uang yang dibutuhkan telah diterima oleh peminjam hutang (rahin). Deng-an adanya qabdhul marhun (penguasaan barang jaminan oleh murtahin), maka akad rahn bersifat mengikat kedua belah pihak.
Sebagaimana telah dikemukakan di atas bahwa dalam ketentuan syariah tidak diatur mengenai jenis pengikatan barang yang dijadikan sebagai jaminan utang. Berdasarkan pemahaman terhadap QS. Al Baqarah : 283 dan Hadis Nabi, maka barang yang dijadikan jaminan utang harus diserahkan dan dikuasai oleh pemberi jaminan (murtahin).

\section{Pemanfaatan Barang Rahn}

Jumhur ulama selain ulama Hambaliyah berpendapat, bahwa pemegang barang jaminan tidak boleh memanfaatkan barang jaminan itu, karena bukan miliknya secara penuh. Hak pemegang barang jaminan terhadap barang itu hanyalah sebagai jaminan piutang yang ia berikan dan apabila orang yang berutang tidak mampu melunasi. utangnya, barulah ia boleh menjual atau menaksir harga barang itu untuk melunasi piutangnya. Apabila ada kelebihan dalam penjualan tersebut, maka wajib dikembalikan kepada pemiliknya.

Apabila pemilik barang mengijinkan pemegang agunan memanfaatkan barang agunan tersebut, maka sebagian ulama Hanafiyah membolehkannya. Sedangkan sebagian ulama lainnya (Hambali, Maliki dan Syafi'i) tidak membolehkannya, karena pemanfaatan atas barang jaminan itu dipandang sebagai riba' yang dilarang oleh syara'. Di samping itu, ridha dan ijin dalam hal ini cenderung dalam keadaan terpaksa, karena khawatir tidak akan mendapatkan uang yang akan dipinjamnya itu.

4. Berakhirnya Akad Rahn

Berakhimya akad Rahn, menurut Wahbah Al Zuhaili dikarenakan beberapa hal::28

a. Barang telah diserahkan kembali kepada pemiliknya.

b. Rahin (penggadai) membayar utangnya.

c. Dijual paksa, yaitu dijual berdasarkan 
penetapan hakim atas permintaan Rahin.

d. Rusaknya barang gadaian oleh tindakan/ penggunaan murtahin.

e. Pembatalan oleh murtahin, meskipun tidak ada persetujuan dari pihak rahin.

f. Rusaknya barang gadaian oleh tindakan atau penggunaan murtahin.

g. Meninggalnya rahin (menurut Malikiyah) dan atau murtahin (menurut Hanafiyah), sedangkan Syafi'iyah dan Hambaliyah menganggap kematian para pihak tidak mengakhiri akad rahn.

\section{Jaminan Pembiayaan Al Qardh Al Hasan pada Bank Syariah Mandiri}

Pada bank konvensional, "penanggungan" dalam praktiknya diterbitkan dalam bentuk Garansi Bank sebagaimana diatur di dalam Surat Edaran Direktur Bank Indonesia No. 23/ 7/UKU tentang Pemberian Garansi Oleh Bank, tanggal 18 Maret 1991. Ditinjau dari perspektif hukum perbankan konvensional, kafalah (Garansi Bank) merupakan perjanjian penanggungan sebagaimana diatur dalam Pasal 1820 sampai Pasal 1850 KUHPerdata.

Pada Bank Syariah Mandiri, mekanisme dan kewenangan mengenai jaminan pembiayaan Al Qardh Al Hasan diserahkan sepenuhnya kepada LAZNAS BSM Umat. ${ }^{29}$ LAZNAS BSM Umat didukung oleh Sistem Perbankan Syariah, dengan mengajak kepada seluruh masyarakat menyisinkan dan menyalurkan harta mereka untuk dioptimalkan dan dilipatgandakan manfaatnya dalam program pemberdayaan dan pendayagunaan untuk menciptakan lapangan kerja baru, menguatkan usaha kecil. ${ }^{30}$ Dalam hal ini, pihak Muqtaridh (peminjam) tidak selalu disyaratkan oleh pihak Muqridh (pemberi pinjaman) sebagaimana ketentuan dalam pembiayaan $A l$ Qardh $A l$ Hasan untuk mengembalikan modalnya yang dipinjamnya saja atau bahkan tidak harus mengembalikan modal pinjamannya apabila dalam usahanya benar-benar mengalami kerugian.

Secara teoritis, kafalah dalam perbankan syariah dapat diterapkan dalam bentuk Garansi Bank, yaitu warkat yang diterbitkan oleh bank yang mengakibatkan kewajiban membayar terhadap pihak yang menerima garansi apabila pihak yang dijamin cidera janji (wan prestasi). Bank dalam pemberian garansi ini dapat meminta setoran jaminan sejumlah tertentu (sebagian atau seluruhnya) dari total nilai objek yang dijaminkan. Dalam pemberian Garansi Bank, bank dapat memungut upah sebagai ujrah (fee).

Analog dengan fatwa Dewan Syariah Nasional No. 34/DSN-MUI//X/2002 tanggal 14 September 2002 tentang L/C Impor Syariah, besarnya ujrah harus disepakati di awal akad dan dinyatakan dalam bentuk nominal, bukan dalam bentuk prosentase. Berdasarkan prinsip-prinsip kafalah di atas, maka pembiayaan Al Qardh Al Hasan diperbolehkan

${ }^{28}$ Wahbah Al Zuhaili, op.cit., jlid V, hlm. 288 - 289

${ }^{29}$ LAZNAS BSM Umat adalah lembaga amil zakat yang lahir dari sebuah kesadaran yang tulus untuk meningkatkan kepedulian sosial dan meringankan penderitaan sesama. LAZNAS BSM Umat merupakan lembaga nirlaba resmi yang eksistensinya diakui sejak 17 September 2002, melalui SK Menteri Agama RI No. 406 Tahun 2002, untuk memudahkan dan memfasilitasi kebutuhan masyarakat muzakidalam menyalurkan dananya kepada mereka yang membutuhkan dengan tepat jaringan dan berdaya guna.

${ }^{30} \mathrm{http}: / /$ www.syariahmandiri.co.id/lazbsmumat/profil.php, diakses.23 Desember 2004. 
karena banyak mengandung kemaslahatan yang terkandung di dalamnya dalam rangka hubungan antar sesama manusia (hablumminannas).

Berdasarkan analisis terhadap prinsip Al Qardh Al Hasan di atas dan hubungannya dengan bentuk-bentuk pengikatan jaminan yang ada serta dengan memperhatikan tujuan pembiayaan Al Qardh Al Hasan yang secara khusus adalah untuk membantu masyarakat tidak mampu (kaum dhuafa, para pengusaha kecil dan mikro di daerah-daerah), maka pembiayaan Al Qardh Al Hasan ini dapat diterapkan di Bank Syariah Mandiri guna memperoleh dana tunai secara cepat dengan menunjukkan bukti-bukti terkait dengan usaha yang dikelolanya sebagai jaminan bahwa ia mampu mengembalikan pinjaman tersebut sesuai akad.

\section{Simpulan}

Pembiayaan Al Qardh Al Hasan pada Bank Syariah Mandiri Cabang Yogyakarta, pada awalnya menupakan akad tabam' (kebaikan) dan ta'awun (saling tolong-menolong) antar sesama manusia, namun dalam perkembangannya sebagai salah satu bentuk usaha atau kegiatan pemberian pinjaman bank (sebagai pihak Muqridh) kepada pihak kedua (sebagai pihak Muqtaridh) untuk kebutuhan mendesak atau sebagai dana talangan (over draft) dengan kriteria tertentu dan bukan untuk pinjaman yang bersifat konsumtif. Dana talangan tersebut dikembalikan sesuai dengan jumlah yang diterima dan pembayarannya dapat dilakukan secara angsuran atau sekaligus.

Kekuatan mengikat akad jaminan pembiayaan AI Qardh AIH Hasan pada Bank Syariah Mandiri Cabang Yogyakarta, menunjukkan bahwa ketentuan syariah tidak mengatur mengenai jenis pengikatan jaminan (barang agunan). Tata cara pengikatan terhadap barang agunan harus berpedoman kepada ketentuan-ketentuan yang berlaku dalam hukum konvensional sebagai ketentuan publikyang mengikat perbankan syariah di Indonesia, yaitu untuk barang tidak bergerak diikat secara Akta Pengikatan Hak Tanggungan dan Hipotek untuk Kapal.

\section{Daftar Pustaka}

Abdul Azis Dahlan, Ensiklopedia Islam, Ichtiar Baru Van Hoeve, Jakarta, 1994

Faisal Afif et-al, Strategidan Operasional Bank, (Bandung, Eresco, 1996

Ibnu Rusyd, Bidayah al Mujtahid wa Nihayah

wa al Muqtadhid, Vol. 3, Dar al Fikr, Beirut, Libanon, tanpa tahun

Ibnu Taimiyah, Majmu al Fatawa Shaikh al Islam,

Riyadh, Maktabi al Riyadh, 1963, Vol. XXIX

Muhammad Said Hisyam, "Pemanfaatan

Produk Bank Islam/Kredit Untuk Mendukung Lingkaran Bisnis Amanah", Makalah Seminar Nasional Bank Umum Tanpa Bunga, Bandung, FE UNPAD, 1991

Muhammad Syafi'i Antonio, "Perkembangan

Lembaga Keuangan Islam", dalam buku Arbitrase Islam Di Indonesia, BMIBAMUI, 1994

R. Subekti, Jaminan-jaminan untuk Pemberian

Kredit menurut Hukum Indonesia, Bandung, Citra Aditya Bakti, 1991

Wahbah Azzhaily, Al Figh al Islam wa Adillatuh, (Damaskus, Dar al Fikr, 1989, Jilid V), hlm. 132, lihat pula Sayyid Sabiq, Figh al Sunnah, Beirut, Dar al Fikr, 1992, jilid III Wahbah Azzuhaily, ibid, hlm.140-147. Lihat juga, Dewan Syariah Nasional, 
Himpunan Fatwa DSN-MUI, BI dan DSN, Jakarta, 2001

Warkum Sumitro, Asas-asas Perbankan Islam Dan Lembaga-lembaga Terkait Di indonesia, Jakarta, Raja Grafindo Persada, 1992 Zainulbahar Noor, Membangun Citra Lewat Pengamalan Syariah, Jakarta, Grasindo, 1993

Undang-Undang Nomor 10 Tahun 1998 tentang Perbankan

Undang-Undang Nomor 23 Tahun 1999 tentang Bank Indonesia

SuratEdaran Bank Indonesia No. 26/1/BPPP, 1993.

Surat Keputusan Deputi Gubernur Senior Bank Indonesia No. 1/1/KEP.DGS/1999 mengubah nama menjadi PT Bank Syariah Mandiri (BSM)
Surat Keputusan Gubernur Bank Indonesia No.1/24/KEP.GBI/1999 tentang Perubahan Kegiatan Usaha Menjadi Berdasarkan Syariah

http://www.bmtlink.web.id/kamusbmt.htm, diakses 14 Oktober 2004

http://www.bmtlink.web.id/kamusbmt.htm, diakses 15 September 2004

http://www.bprsyariah.com/subbiaya.php, diakses 15 September 2004.

http:/www.pikiran-rakyat.com/cetak/0303/03/ 0807.htm, diakses 15 September 2004. http://www.pikiran-rakyat.com/cetak/1003/01/ 0105.htm, diakses 15 September 2004 http:/www.syariahmandiri.co.id/lazbsmumat/ profil.php, diakses 23 Desember 2004 